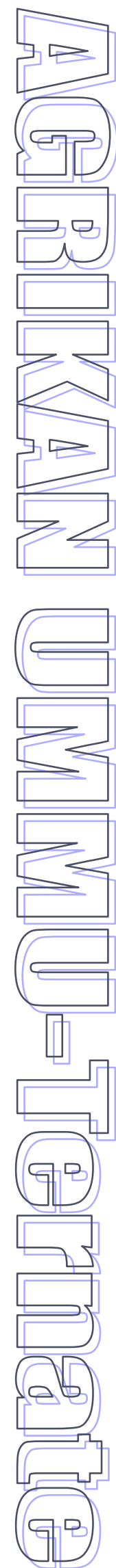

baik faktor luar (external) maupun dari dalam (internal) dimana faktor internal diantaranya ialah keturunan, sex, umur dan penyakit sedangkan faktor eksternal yang utama mempengaruhi pertumbuhan ikan yaitu makanan dan suhu perairan (Effendie, 2002). Lebih lanjut di katakan bahwa hubungan panjang-berat menunjukan pertumbuhan yang relatif yang artinya dapat berubah menurut waktu. Apabila terjadi perubahan lingkungan dan ketersediaan makanan diperkirakan nilai $b$ juga akan berubah.

Berdasarkan hasil uji koefisien korelasi (r) digunakan untuk melihat sejauh mana keeratan hubungan dua variabel. Nilai koefisien korelasi (r) yang diperoleh untuk ikan lolosi biru betina yaitu 0,9381. Hal ini menunjukan bahwa terdapat hubungan keeratan antara panjang dan berat dari ikan lolosi biru betina sebesar 94\%. Untuk ikan lolosi biru jantan nilai koefisien korelasi (r) yang diperoleh yaitu 0,9820. Hal ini menunjukan bahwa terdapat hubungan keeratan antara panjang dan berat dari ikan lolosi biru jantan sebesar $98 \%$. Dari hasil uji koefisien korelasi sebagaimana yang ditemukan baik jantan maupun betina menunjukan hubungan yang positif yang artinya regresinya saling mempengaruhi sehingga pertambahan berat selalu diikuti dengan pertambahan panjang.

Berbagai penelitian telah banyak dilakukan terutama yang berkaitan dengan aspek bioreproduksi dari famili Caesionidae yang diantaranya dilaksanakan dipulau seribu. Dari hubungan panjang berat ikan ekor kuning (C. tuning) diperairan pulau seribu menunjukan hubungan positif dengan nilai korelasi sebesar $0.99 \%$ dengan pola pertumbuhan isometrik $(b=3,021)$ (Jabbar, $M$. 2008).

\subsection{Tingkat Kematangan Gonad}

Tingkat kematangan gonad ikan lolosi biru (C. caerulaureus)yang di amati hanya pada ikan betina, yaitupengamatan berdasarkan ciri-ciri morfologinya meliputi bentuk gonad, panjang-berat gonad, warna gonad dan perkembangan isi gonad. Perubahan yang terjadi pada komposisi tingkat kematangan gonad (TKG) ikan lolosi biru (C. caerulaureus) betina yang diperoleh selama penelitian dapat dilihat pada histogram pada Gambar 3.

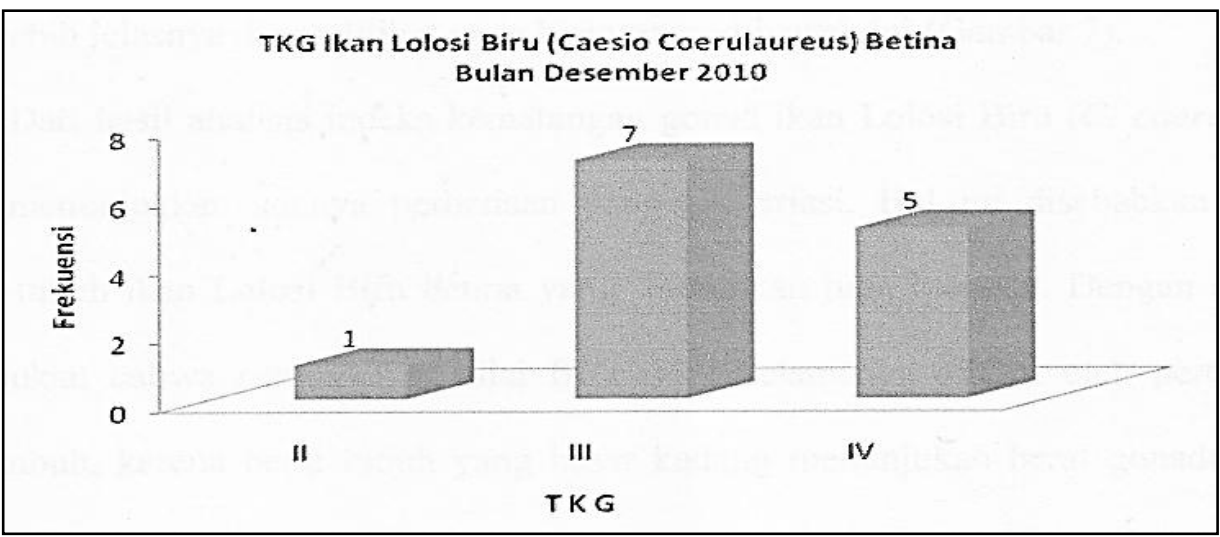

Gambar 3. Histogram frekuensi TKG Ikan lolosi biru (C. caerulaureus) betina.

Berdasarkan Gambar 3 diatas menunjukan bahwa komposisi frekuensi Tingkat Kematangan Gonad (TKG) yang ditemukan pada ikan lolosi biru (C. caerulaureus) betina terdiri dari tahap, TKG III dan TKG IV dengan jumlah total sampel sebanyak 12 ekor.

Frekuensi tingkat kematangan gonad dengan jumlah spesies terbanyak ditemukan pada tahap TKG III dengan jumlah spesies 7 ekor, selanjutnya TKG IV dengan jumlah spesies 5 ekor.

Tingkat kematangan gonad adalah tahap tertentu perkembangan gonad sebelum dan sesudah ikan memijah. Kematangan gonad ikan diperlukan antara lain untuk mengetahui perbandingan antara ikan yang sudah matang gonad dengan yang belum matang gonad dari 


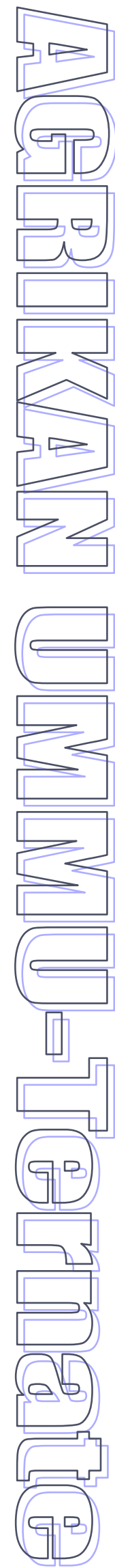

suatu sedian, ukuran atau umur ikan pertarna kali matang gonad, apakah ikan sudah memijah atau belum, waktu pemijahan, lamanya ikan memijah serta jumlah pemijahan dalarn satu tahun (Effendie, 1992).

Effendie (2002) menyatakan bahwa ikan yang berada pada tahap TKG III (hampir masak) memiliki ciri-ciri gonad mengisi $1 / 2$ rongga tubuh bentuk telur tampak melalui dinding ovarium dan berwarna kuning. Sedangkan ikan yang berada pada tahap TKG IV (masak) memiliki ciri-ciri gonad mengisi $3 / 4$ rongga tubuh berwarna kuning. hampir bening atau bening.

Hasil analisis menunjukan bahwa Ikan lolosi biru (C. caerulaureus) betina, yang tertangkap dibulan Desember tahun 2011 itu semakin mendekati waktu pemijahan. Hal ini dikarenakan dari hasil analisisi terhadap TKG ditemukan frekuensi terbesar pada TKG tahap III dan IV.

Reproduksi Caesionidae telah diteliti pada beberapa spesies, memiliki waktu kematangan yang awal dan fekunditas yang tinggi. Mereka memiliki musim pemijahan yang panjang, namun puncak pemijahan terjadi satu atau dua kali dalam satu tahun. Selanjutnya Jabbar (2008), menyatakan bahwa pemijahan ikan ekor kuning (C. cuning) terjadi disekitar perairan terumbu karang dan terjadi sepanjang tahun.

\subsection{Indeks Kematangan Gonad (IKG)}

Indeks Kematangan Gonad (IKG) menggambarkan suatu nilai yang diperoleh dengan membandingkan bobot gonad dengan bobot tubuh dikalikan seratus persen. Dimana nilai indeks kematangan gonad yang mengalami perubahan tiap waktu menunjukan adanya perkembangan gonad.

Perkembangan gonad ke arah yang lebih matang akan menyebabkan volume dan berat gonad bertambah sehingga kisaran nilai IKG nya akan meningkat pula. Kisaran indeks kematangan gonad ikan lolosi biru pada bulan Desember berkisar 0,27-2,90. Untuk lebih jelasnya dapat dilihat pada histogram pada Gambar 4.

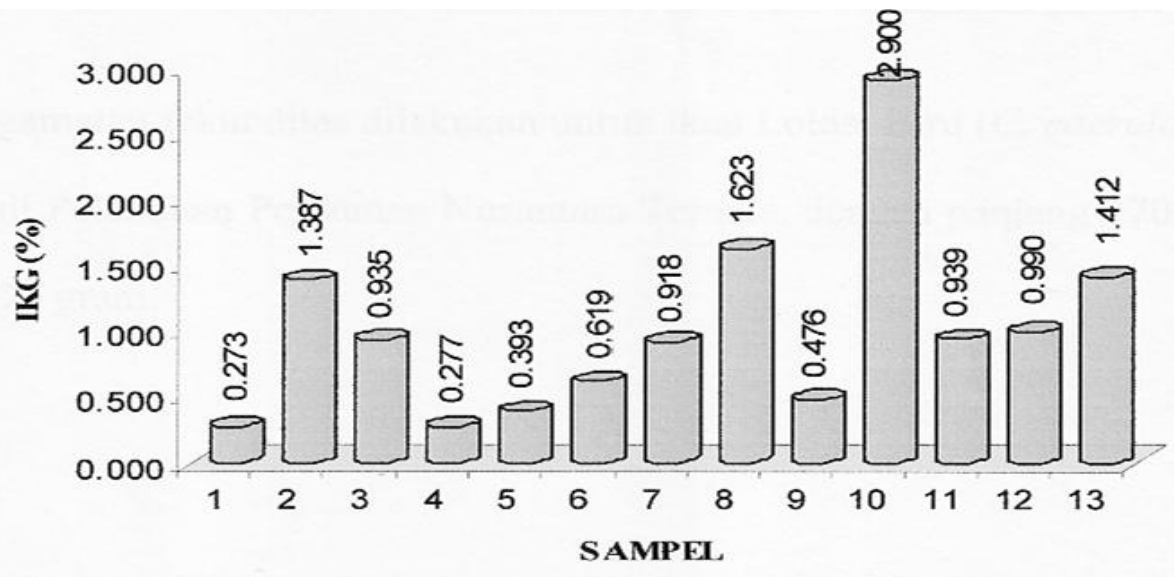

Gambar 4. Kisaran nilai IKG ikan Lolosi Biru Betina (C. caerulaureus)

Indeks kematangan gonad adalah nilai perbandingan antara berat gonad dengan berat tubuh ikan dalam persen (\%) gonad semakin bertambah dengan semakin bertambah ukurannya dan ukuran diameter telur. Berat gonad akan mencapai maksimum sesaat sebelum ikan akan memijah, dengan demikian nilai IKG akan mencapai maksimum pada saat akan terjadi pemijahan (Effendie, 1992). Selanjutnya dikatakan dalam perkembangan gonad, selain perkembangan morfologi juga terdapat perkembangan telur sejalan dengan perkembangan berat gonad.

Perkembangan gonad kearah yang lebih matang akan menyebabkan volume dan berat gonad bertambah sehingga kisaran nilai IKG nya akan meningkat pula. Kisaran indeks kematangan gonad ikan lolosi biru pada bulan Desember 2011 berkisar 0,27-2,90. 
Hasil analisis indeks kematangan gonad ikan lolosi biru (C. caerulaureus) betina menunjukan adanya perbedaan yang bervariasi. Hal ini disebabkan karena ukuran tubuh ikan lolosi biru betina yang ditemukan juga berbeda. Dengan demikian menunjukan bahwa peningkatan nilai IKG tidak selamanya diikuti oleh pertambahan bobot tubuh karena berat tubuh yang besar kadang menunjukan berat gonadnya kecil begitu juga sebaliknya.

\subsection{Fekunditas}

Hasil perhitungan dan pengamatan fekunditas pada ikan lolosi biru betina (C. caerulaureus) di sajikan pada Tabel 5.

Tabel 5. Hasil perhitungan fekunditas ikan lolosi biru (C. caerulaureus) betina.

\begin{tabular}{ccccc}
\hline No. & $\begin{array}{c}\text { Panjang Total } \\
(\mathbf{m m})\end{array}$ & $\begin{array}{c}\text { Berat Tubuh } \\
(\mathbf{g r})\end{array}$ & TKG & $\begin{array}{c}\text { Fekunditas } \\
\text { (butir) }\end{array}$ \\
\hline 1 & 29 & 376 & III & 3564.59 \\
2 & 29 & 326 & III & 7581.51 \\
3 & 27.8 & 298 & IV & 2077.70 \\
4 & 27.5 & 304 & IV & 271.463 \\
5 & 20.5 & 112 & IV & 2874.75 \\
6 & 27.5 & 266 & III & 1912.88 \\
7 & 27.5 & 302 & IV & 1247.71 \\
8 & 29 & 302 & III & 95.1064 \\
9 & 29 & 322 & III & 7.11788 \\
10 & 27 & 300 & III & 1315.16 \\
11 & 29.5 & 354 & IV & 3672.33 \\
12 & 27.5 & 324 & III & 1438.82
\end{tabular}

Fekunditas adalah jumlah telur masak sebelum dikeluarkan pada waktu ikan memijah. Fekunditas demikian disebut fekunditas individu atau fekunditas mutlak sedangkan fekunditas nisbi adalah jumlah telur per satuan berat atau panjang ikan (Nikolisky, 1963). Hasil pengamatan fekunditas ikan lolosi biru (C. caerulaureus) betina di perolah nilai panjang 270-295 $\mathrm{mm}$ dan berat 112-322 gram. Berdasarkan perhitungan ditemukan bahwa fekunditas ikan lolosi biru berkisar antara 7.11788 - 7581.51 butir.

Pengamatan fekunditas ikan lolosi biru betina dilakukan pada ikan - ikan yang matang gonad atau berada pada TKG III dan IV, karena jumlah telur pada tahapan tersebut dianggap maksimum. Nilai rataan fekunditas yang tertinggi yaitu 7581,51 butir dengan panjang total ikan $29 \mathrm{~cm}$ dan berat tubuh 326 gram, sedangkan rataan fekunditas yang terendah yaitu 7,11788 butir dengan panjang total $29 \mathrm{~cm}$ dan berat tubuh 322 gram.Hasil yang di peroleh menunjukkan fekunditasnya bervariasi. Hal ini disebabkan ikan - ikan yang tertangkap memiliki ukuran yang tidak sama sehingga fekunditasnya berbeda antara satu dengan yang lainnya.
Effendie, (1992) mengatakan kegunaan fekunditas adalah sebagai bagian dari studi sistimatik atau studi mengenai ras, dinamika pupulasi, produktivitas, potensi reproduksi dan sebagainya. Sedangkan dalam bidang akuakultur jumlah telur yang dihasilkan berguna dalam persiapan fasilitas kultur ikan.

\section{KESIMPULAN DAN SARAN}

4.1. Kesimpulan

Berdasarkan hasil penelitian terhadap studi aspek bioreproduksi ikan lolosi biru (C. caerulaureus) yang didarat kan diPelabuhan Perikanan Nusantara Ternate maka dapat diberikan kesimpulan sebagai berikut :

1). Pola pertumbuhan dari ikan lolosi biru baik jantan maupun betina yang didaratkan di Pelabuhan Perikanan Nusantara Ternate adalah "allometrik mayor" yang artinya pertambahan berat lebih cepat dari pertambahan panjang.

2). Tahapan kematangan gonad yang mendominasi pada ikan lolosi biru betina adalah TKG III dan TKG IV, sehinga menunjukan bahwa ikan lolosi biru (C. caerulaureus) betina yang tertangkap 
dibulan Desember 2011 semakin mendekati waktu pemijahan.

3). Rata-rata fekunditas berfluktuasi antara 7.11788 - 7581.51 butir.

\subsection{Saran}

Berdasarkan kesimpulan diatas maka disarankan agar penelitian lebih lanjut dapat dilakukan tentang studi aspek biorepruduksi ikan lolosi biru (C. caerulaureus) agar dapat diketahuii lebih jelas musim puncak pemijahan dari ikan lolosi biru. Sehinga menjadi informasi dan rekomendasi yang komperhensif bagi usaha penangkapan ikan lolosi biru di Maluku Utara.

\section{DAFTAR PUSTAKA}

Djamali. A. Mubarak. H. 1998. Sumberdaya Ikan Konsumsi Perairan Karang, dalamPotensi dan Penyebaran Sumberdaya ikan Laut di Perairan Indonesia, Jakarta,Widodo, J., Aziz, K.A., Priyono, B.E., Tampubolon, G.H., Naamin, N., Djamali, A., Editor, Komisi Nasional Pengkajian Stok Sumberdaya Ikan Laut, 195-200.

Effendie. M. 1. 1979. Metode Biologi Perikanan. Cetakan Pertama.Yayasan Dewi Sri. Bogor. 112 hal. Effendie. M.I. 1992. Metode Biologi Perikanan. Yayasan Dewi Sri. Bogor. 112 hal. Fujaya. Y. 2004.

Fisiologi Ikan. Dasar Pengembangan Teknik Perikanan. Rineka Cipta.

Effendie. M.I. 2002. Biologi Perikanan. Yayasan Pustaka Nusatama. Bogor.

Jabbar M.A. 2008. Pengelolaan Sumberdaya Perikanan ekor Kuning (Caesio cuning) di Perairan Kepulauan Seribu. Tesis. Program Studi pengelolaan sumberdaya Hayati dan Lingkungan Hidup Tropika. Tesis Program Pascasarjana Institut Teknologi Bandung (ITB) Bandung. Tidak dipublikasikan.

Nikolsky. N. 1963. The Ecology of Fishes.Academic Press. New York. 325 pp.

Peristiwady Teguh. 2006. Ikan-Ikan Laut Ekonomis Penting di Indonesia. Petunjuk Identifikasi. LIPI Press.Jakarta. 


\title{
STUDI PADA KUALITAS BUBUK BIJI KAKAO LINDAK SEBAGAI PEMBANDING PADA PRODUK KAKAO BUBUK KOMERSIAL
}

\author{
Mustamin Anwar Masuku \\ Staf Pengajar FAPERTA UNKHAIR-Ternate, $e$-mail: -
}

\begin{abstract}
ABSTRAK
Tujuan dari penelitian ini adalah untuk mengolah biji kakao menjadi kakao bubuk, mengetahui kualitas produk akhir yang dihasilkan serta membandingkannya dengan produk kakao bubuk komersial dan menentukan titik kendali kualitas kakao bubuk dalam pengolahannya dari biji kering. Hasil penelitian menunjukkan bahwa Kadar air kakao bubuk yang dibuat selama penelitian relatif lebih rendah daripada kakao bubuk komersial (10,35\%), merupakan kadar air yang masih ideal untuk produk bubuk. Kadar lemak kakao bubuk yang dibuat selama penelitian relatif lebih tinggi dibandingkan dengan kadar lemak kakao bubuk komersial. Laju pengendapan kakao bubuk yang dibuat selama penelitian relatif lebih tinggi daripada laju pengendapan kakao bubuk komersial. warna dan tekstur kakao bubuk yang dibuat selama penelitian dinilai kurang kompetitif jika dibandingkan dengan kakao bubuk komersial. Kakao bubuk cukup disukai dari sisi rasa dan tekstur, setara dengan kakao bubuk komersial. Tahap pengecilan ukuran dan pemanasan sebelum pemisahan lemak menjadi titik kendali kualitas kakao bubuk.
\end{abstract}

Kata Kunci: Cocoa powder quality, method, and determinant point quality

\section{PENDAHULUAN}

1.1 Latar Belakang

Produksi biji kakao nasional saat ini sebagian besar diorientasikan untuk kepentingan ekspor sebagai bahan baku produk antara dan produk akhir. Produk antara dan produk akhir yang dihasilkan selanjutnya dipasarkan kembali ke Indonesia untuk memenuhi kebutuhan masyarakat. Kondisi ini menjadikan masyarakat Indonesia hanya sebagai konsumen yang tidak mendapatkan manfaat dari timbulnya penambahan nilai dari pengolahan biji kakao menjadi produk antara dan produk akhir yang siap dikonsumsi.

Komitmen bangsa Indonesia untuk menuju kemandirian pangan menuntut perubahan kondisi tersebut. Salah satu langkah yang dapat diambil dalam rangka ini adalah dengan memulai pengolahan biji kakao menjadi produk antara dan produk akhir di Indonesia. Oleh karena itu perlu mengenalkan proses pengolahan biji kakao menjadi kakao bubuk kepada masyarakat. Pengenalan proses ini pada masyarakat diharapkan akan melatih masyarakat untuk dapat melakukan proses pengolahan bahan pangan dan mampu menganalisa faktor-faktor yang berpengaruh pada produk akhir selama proses pengolahan. Lebih jauh, pengenalan proses pengolahan semacam ini diharapkan akan mendorong munculnya semangat untuk berkarya, mengolah potensi bangsa seoptimal mungkin dengan cara yang dapat dipertanggungjawabkan secara ilmiah.

1.2. Tujuan Penelitian

Penelitian ini bertujuan untuk :

1. Untuk mengolah biji kakao menjadi kakao bubuk.

2. Untuk mengetahui kualitas produk akhir yang dihasilkan serta membandingkannya dengan produk kakao bubuk komersial. 
3. Untuk menentukan titik kendali kualitas kakao bubuk dalam pengolahannya dari biji kering.

\section{BAHAN DAN METODE PENELITIAN}

\subsection{Bahan}

Bahan utama digunakan dalam penelitian ini adalah biji kakao setengah kering matahari dari buah kakao varietas buah kakao lindak (Upper Amazon Hybrid) dari kebun rakyat Sulawesi Tenggara. Buah kakao lindak yang digunakan dipilih yang seragam dan masak optimal, sebanyak \pm 15 polong untuk mendapatkan biji kakao setengah kering matahari sebanyak $1 \mathrm{~kg}$. Peralatan untuk pembuatan kakao bubuk sebagai berikut: Timbangan beban geser, timbangan rumah, oven pengering, food processor, pengempa, dan mesin penyaring. Adapun alat penguji kualitas kakao bubuk sebagai berikut: timbangan analitik Sartorius A 200S, Infra red Moisture Tester, soxtec, timbangan ekstraktor, tabung penampung Corong, Labu ukur, Gelas beker,
Magnetic stirer dengan pemanas, Gelas ukur, Timer.

Diagram alir pembuatan kakao bubuk dari biji kakao dapat dilihat pada Gambar 1.

\subsection{Prosedur Uji Kualitas Kakao Bubuk}

Kakao bubuk yang dihasilkan dari masing-masing perlakuan dianalisa kadar air, kadar lemak, laju pengendapan dan uji organoleptiknya bersamaan dengan kakao bubuk komersial sebagai pembanding (Sudarmadji, S., B. Haryono dan Suhardi. 1996).

\subsubsection{Kadar Air}

Kadar air kakao bubuk dianalisa dengan peralatan Infra Red Moisture Tester. Sampel sebanyak 1 - 2 gram diletakkan pada bidang aluminium foil secara tipis merata kemudian diletakkan pada alat pengukur kadar air lalu ditutup. Alat kemudian dioperasikan. Setelah sekitar 5 menit, alat akan mengeluarkan bunyi pertanda berat konstan telah dicapai dan panel LCD menunjukkan kadar air dari sampel.

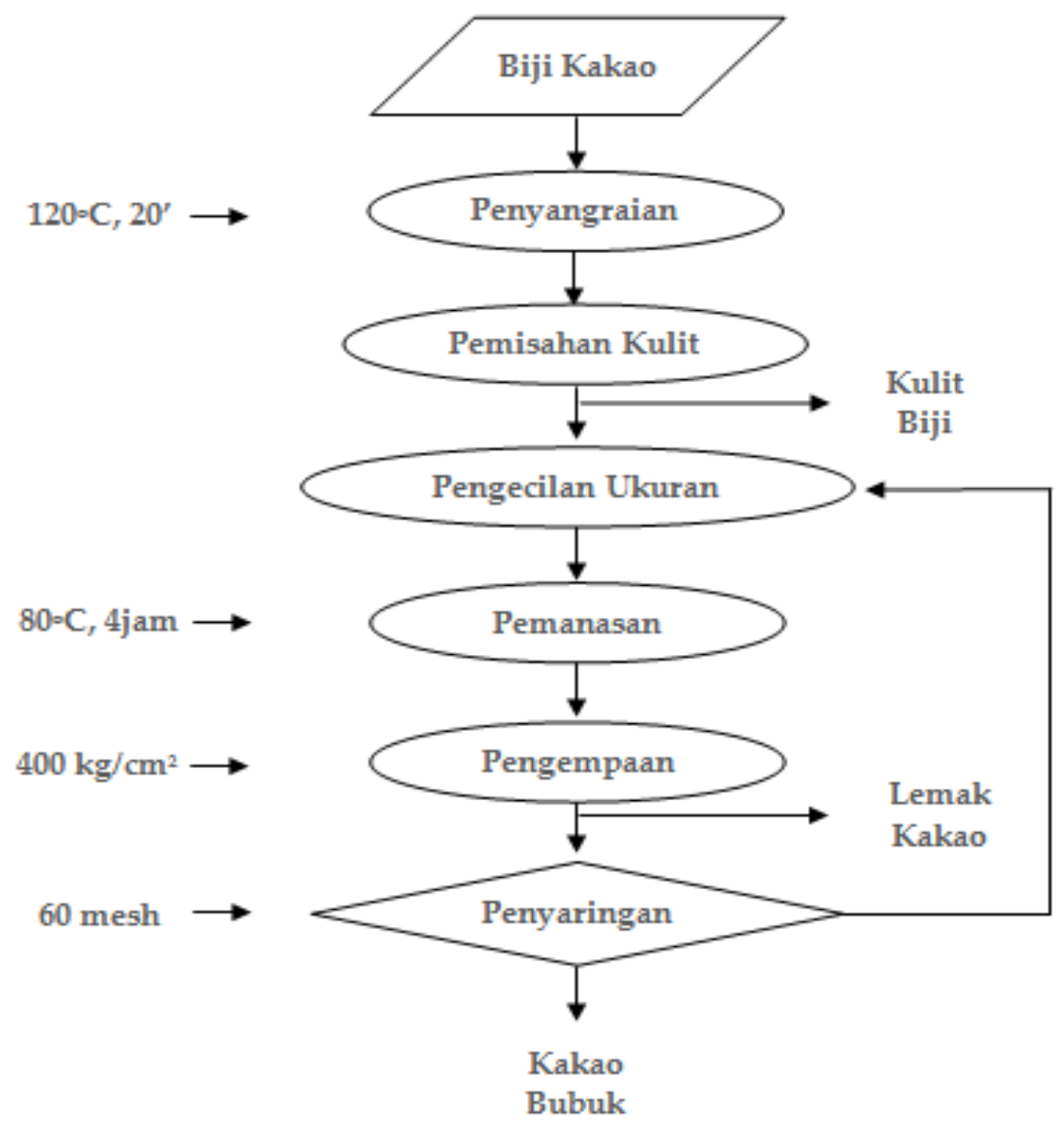

Gambar 1. Diagram Alir Pembuatan Kakao Bubuk 


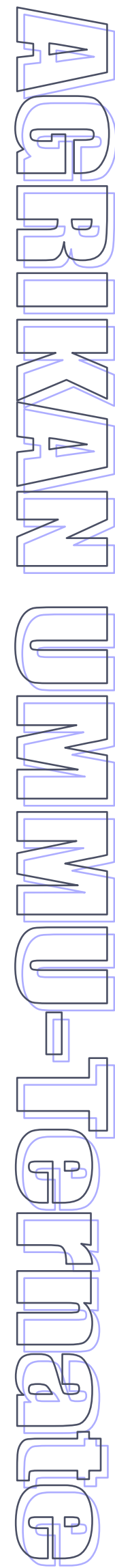

\subsubsection{Kadar Lemak}

Kadar lemak kakao bubuk dianalisa dengan menggunakan Soxtec extractor lemak. Sampel yang telah diketahui beratnya (lebih kurang 2 g) ditempatkan dalam tabung extractor. Tabung extractor kemudian ditempatkan pada tabung penampung yang telah diketahui berat konstannya.

Kedua tabung kemudian dimasukkan ke dalam alat Soxtec untuk dilakukan ekstraksi menggunakan pelarut hexane. Ekstraksi dilakukan pada suhu $134^{\circ} \mathrm{C}$. Setelah kurang lebih 2 jam, ekstraksi berakhir. Tabung penampung kemudian ditimbang dengan terlebih dahulu dioven untuk memperoleh berat konstan. Selisih berat tabung sebelum dan sesudah ekstraksi dianggap sebagai berat lemak.

\subsubsection{Laju Pengendapan}

Laju pengendapan diamati untuk mengetahui waktu kakao bubuk dalam larutan. Pengamatan ini sekaligus mencerminkan kelarutan kakao bubuk. Sampel sebanyak 1,5 g dimasukkan dalam gelas beker $50 \mathrm{ml}$ yang telah berisi air sebanyak $50 \mathrm{ml}$ kemudian diaduk pada suhu $70{ }^{\circ} \mathrm{C}$ hingga rata. Larutan kemudian dituang ke dalam gelas ukur $100 \mathrm{ml}$ dan didiamkan selama 10 menit. Tinggi endapan yang terbentuk dibandingkan dengan skala pada dinding gelas ukur.

2.2.4. Sifat Organoleptik: (Warna, Tekstur,

\section{Kesukaan)}

Kualitas organoleptik kakao bubuk yang telah dibuat dibandingkan dengan kakao bubuk komersial. Kualitas organoleptik yang diamati meliputi warna, tekstur dan rasa. Pengamatan dilakukan secara hedonik dengan skoring oleh 15 orang panelis semi-terlatih. Instrumen yang digunakan untuk uji sifat sensoris organoleptik dan kesukaan organoleptik adalah quisioner seperti pada Tabel 1.

\subsection{Tingkat Kesukaan}

Tingkat kesukaan panelis terhadap sampel kakao bubuk diukur dengan instrumen kuisioner pada Tabel 2.

Tabel 1. Instrumen Pengujian Sifat Sensorik Organoleptik Kakao Bubuk

\begin{tabular}{lccc}
\hline & 964 & 738 & 875 \\
\hline Warna & $1-2-3-4$ & $1-2-3-4$ & $1-2-3-4$ \\
Tekstur & $1-2-3-4$ & $1-2-3-4$ & $1-2-3-4$ \\
Rasa & $1-2-3-4$ & $1-2-3-4$ & $1-2-3-4$ \\
\hline
\end{tabular}

$\begin{array}{ll}\text { Keterangan } & \\ \text { - Warna } & : 1 \text { (coklat cerah), } 2 \text { (coklat), } 3 \text { (coklat agak gelap), } 4 \text { (coklat gelap) } \\ \text { - Tekstur } & : 1 \text { (amat halus), } 2 \text { (halus), } 3 \text { (agak halus), } 4 \text { (agak kasar) } \\ \text { - Rasa } & : 1 \text { (tawar), 2 (agak pahit), } 3 \text { (pahit), } 4 \text { (sangat pahit) }\end{array}$

$\begin{array}{ll}\text { - Tekstur } & : 1 \text { (amat halus), } 2 \text { (halus), } 3 \text { (agak halus), } 4 \text { (agak kasar) } \\ \text { - Rasa } & : 1 \text { (tawar), } 2 \text { (agak pahit), } 3 \text { (pahit), } 4 \text { (sangat pahit) }\end{array}$

Tabel 2. Instrumen Pengujian Tingkat Kesukaan

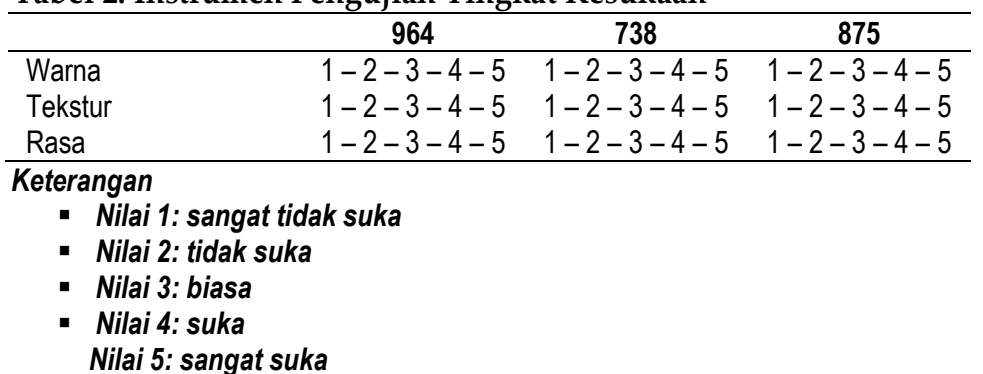

\section{HASIL DAN PEMBAHASAN}

\subsection{Kadar Air}

Kadar air berpengaruh pada keawetan kakao bubuk. Kakao bubuk dengan kadar air yang rendah lebih terjamin keawetannya. Kakao bubuk yang dihasilkan dengan pengolahan selama penelitian dan kakao bubuk komersial mengandung air dengan kadar tercantum pada Tabel 3.
Logika yang mungkin dapat menjadi pembenar bagi perbedaan kadar air keempat sampel adalah sebagai berikut. Kakao bubuk tidak lolos penyaringan memiliki kadar air paling rendah karena relatif tidak bersifat higroskopis karena ukuran partikel paling besar dan menggumpal, saling bergabung satu dengan yang lain. 
Biehl, 1984 mengatakan bahwa kakao bubuk lolos penyaringan pertama mengandung air dengan kadar sedikit lebih tinggi karena ukuran partikel yang lebih kecil sehingga lebih bersifat higroskopis. Kakao bubuk lolos penyaringan kedua sebenarnya memiliki tingkat higroskopis yang relatif sama denga kakao lolos penyaringan pertama. Namun karena lebih lama terekspos di udara terbuka selama perlakuan ulang (pengecilan ukuran, pemanasan, pengempaan dan penyaringan). Adapun kakao bubuk komersial, kandungan airnya yang paling besar karena ukuran partikelnya yang paling kecil sehingga paling bersifat higroskopis.

\subsection{Kadar Lemak}

Lemak kakao merupakan lemak alami yang diperoleh dari biji kakao dengan cara pengempaan atau pelarutan. Biji kakao yang telah disangrai, dipisahkan dari kulitnya, diperkecil ukurannya dan dipanaskan kemudian dimasukkan ke dalam alat kempa hidrolis yang memiliki dinding silinder yang diberi lubang-lubang sebagai penyaring. Menurut Biehl dkk (1989), cairan lemak selanjutnya keluar melewati lubang-lubang tersebut, sedangkan bungkil cokelat sebagai hasil sampingnya akan tertahan di dalam silinder. Bungkil inilah yang selanjutnya akan dijadikan bubuk.

Tabel 3. Kadar Air Empat Kelompok Kakao Bubuk

\begin{tabular}{lrrr}
\hline \multicolumn{1}{c}{ Sampel } & Kadar air I (\%) & Kadar air II (\%) & Rata-rata (\%) \\
\hline Lolos penyaringan I & 6,56 & 6,75 & 6,66 \\
Lolos penyaringan II & 9,98 & 7,60 & 8,79 \\
Tidak lolos penyaringan & 5,70 & 6,32 & 6,01 \\
Komersial & 10,31 & 10,39 & 10,35 \\
\hline
\end{tabular}

Tabel 4. Kadar Lemak Empat Kelompok Kakao Bubuk

\begin{tabular}{|c|c|c|c|c|c|c|c|c|}
\hline \multirow{3}{*}{ Parameter } & \multicolumn{8}{|c|}{ Sampel (ulangan) } \\
\hline & \multicolumn{2}{|c|}{1} & \multicolumn{2}{|c|}{2} & \multicolumn{2}{|l|}{3} & \multicolumn{2}{|c|}{4} \\
\hline & $\mathrm{I}$ & II & $\mathrm{I}$ & II & $\mathrm{I}$ & II & $\mathrm{I}$ & II \\
\hline Berat sampel $(\mathrm{g})$ & 2,0621 & 2,1380 & 2,1513 & - & 2,2074 & - & 2,0479 & 2,0190 \\
\hline Berat tabung awal (g) & 46,8559 & 46,5217 & 46,6940 & - & 46,9946 & - & 46,6255 & 47,1002 \\
\hline Berat tabung akhir (g) & 47,6140 & 47,3425 & 47,3937 & - & 47,7646 & - & 46,8729 & 47,3853 \\
\hline Berat lemak (g) & 0,7581 & 0,8208 & 0,6997 & - & 0,7700 & - & 0,2474 & 0,2851 \\
\hline Kadar lemak (\%) & 36,7634 & 38,3910 & 32,5245 & - & 34,8826 & - & 12,0807 & 14,1209 \\
\hline
\end{tabular}

Lemak kakao berwarna kuning muda, pada suhu kamar berbentuk padat namun rapuh/getas, titik leleh $35^{\circ} \mathrm{C}$, angka penyabunan 188-198, angka iod 35-40, asam lemak bebas sebagai asam oleat yang diijinkan 1,5\%. Hasil uji kadar lemak keempat sampel kakao bubuk dengan Soxtec tercantum pada Tabel 4.

Kakao bubuk lolos penyaringan pertama mengandung lemak dengan kadar paling besar. Kakao bubuk lolos penyaringan kedua mengandung lemak dengan kadar yang lebih kecil karena kakao bubuk ini diperoleh melalui dua kali pengempaan sehingga lemaknya sudah lebih banyak berkurang. Kakao bubuk tidak lolos penyaringan mengandung lemak dengan kadar di antara keduanya karena meskipun mengalami dua kali pengempaan tetapi kemungkinan menjadi bagian dengan gumpalan lemak besar yang menjadikannya saling bergabung dan tidak lolos dalam penyaringan. Johnson dkk, 1984 mengatakan bahwa adapun kakao bubuk komersial, kandungan lemaknya yang sangat rendah kemungkinan disebabkan oleh proses pemisahan lemaknya yang disertai dengan pelarutan menggunakan zat pelarut lemak.

Minifie B W and Chem (1984), mengatakan bahwa kadar lemak pada umumnya dinyatakan dalam persen dari berat kering keping biji. Lemak merupakan komponen termahal dari biji kakao sehingga nilai ini dipakai oleh konsumen sebagai salah satu tolok ukur penentuan harga. Selain oleh bahan tanam dan musim, kandungan lemak dipengaruhi oleh perlakuan pengolahan, jenis bahan tanaman dan faktor musim. Biji kakao yang berasal dari pembuahan musim hujan umumya mempunyai kadar lemak lebih tinggi. Sedang, karakter phisik biji kakao pasca pengolahan, seperti kadar air, tingkat fermentasi dan kadar kulit, berpengaruh pada randemen lemak biji kakao. Kisaran 